\title{
Nucleotide sequence of a Lactococcus lactis gene cluster encoding adenylate kinase, initiation factor 1 and ribosomal proteins
}

\author{
TeIJA KoIvUla* and HaRri Hemilä \\ Institute of Biotechnology, University of Helsinki, Valimotie 7, SF-00380 Helsinki, Finland
}

(Received 2 May 1991; revised 19 July 1991; accepted 15 August 1991)

\begin{abstract}
We have previously isolated a putative promoter from the Lactococcus lactis subsp. lactis chromosome. We now report the sequence of the promoter fragment and its extension in the 5 -direction. The region contains several open-reading frames which correspond to ribosomal protein L15, SecY, adenylate kinase, initiation factor 1 and ribosomal proteins B and S13. The order of the genes, $r p l O$ (L15), $\sec Y, a d k, \inf A, r p m J(B)$ and $r p s M(\mathrm{S13})$, is similar to that in the spc and $\alpha$ operon region of Bacillus subtilis, with the exception of the map gene, coding for methionine amino peptidase, which is located between $a d k$ and inf $A$ in $B$. subtilis. The putative promoter is located between $a d k$ and $\inf A$.
\end{abstract}

\section{Introduction}

The biochemistry and genetics of ribosomal proteins have been extensively studied in Escherichia coli, which has over 50 ribosomal protein genes (Lindahl \& Zengel, 1986; Bachmann, 1990). Several of the proteins have been purified and characterized, and most of the genes have been isolated and sequenced. The genes are scattered around the chromosome. Nevertheless, approximately half of them map at $73 \mathrm{~min}$ on the $E$. coli chromosome, at the $s t r-s p c$ locus, which is organized into the four transcription units str, S10, spc and $\alpha$. In Bacillus subtilis, an extensively studied Gram-positive bacterium, about 40 ribosomal genes have been localized (Piggot $e t$ al., 1990). Similarities between the ribosomal operons of $E$. coli and $B$. subtilis have been found in the $s p c$ and $\alpha$ regions (Boylan et al., 1989; Henkin et al., 1989).

The $s p c$ and $\alpha$ operons contain genes for ribosomal proteins but also some other genes. In $E$. coli, this region contains a gene for the $\alpha$ subunit of the DNA-dependent RNA polymerase, and a gene for SecY, a protein involved in protein secretion (Cerretti et al., 1983; Bedwell et al., 1985). These genes are also included in the $s p c-\alpha$ region of $B$. subtilis, which, in addition, includes genes for adenylate kinase (Adk), methionine amino peptidase (Map) and initiation factor 1 (IF1) (Boylan et al., 1989; Nakamura et al., 1990; Suh et al., 1990). Adk

The nucleotide sequence data reported in this paper have been submitted to EMBL and have been assigned the accession number X59250. catalyses the reaction ATP + AMP $\rightarrow 2$ ADP (Schulz et $a l ., 1986)$ and Map removes the amino-terminal formylmethionine from cellular proteins (Ben-Bassat et al., 1987). IF1 participates in protein synthesis by forming the initiation complex with IF2 and IF3, although the exact role of IF1 in this process is not known (Pon et al., 1979).

Lactococci are important micro-organisms in food and feed fermentations; this has resulted in considerable efforts to understand their molecular biology. However, there are no data on the ribosomal proteins or their genes in lactococci. We have previously isolated chromosomal promoter fragments from L. lactis subsp. lactis (Koivula et al., 1991b). One of the cloned DNA fragments contained three open-reading frames (ORFs) downstream from the promoter. The ORFs corresponded to IF1 and to the ribosomal proteins B and S13. In this paper we report a nucleotide sequence for the region of the $L$. lactis chromosome which closely resembles the end of the $s p c$ operon and the beginning of the $\alpha$ operon of $E$. coli and $B$. subtilis.

\section{Methods}

Bacterial strains, plasmids and culture conditions. L. lactis subsp. lactis MG1614 (Gasson, 1983) was the source of chromosomal DNA. E. coli DH5 $\alpha \mathrm{F}^{\prime}$ (Hanahan, 1983) was used as a cloning host for plasmid constructions based on pUC18 and pUC19 (Yanisch-Perron et al., 1985). B. subtilis IH6064 (Palva, 1982) was the source of chromosomal DNA used as a control in hybridization. The plasmid pKTH1816 has been described previously (Koivula et al., 1991 b). 
E. coli and B. subtilis cells were grown in Luria broth (Maniatis $e$ al., $1982)$ supplemented with ampicillin $\left(100 \mu \mathrm{g} \mathrm{ml}^{-1}\right)$ as necessary. L. lactis cells were grown in M17/glucose (Terzaghi \& Sandine, 1975) medium supplemented with chloramphenicol $\left(5 \mu \mathrm{g} \mathrm{ml}^{-1}\right)$ as needed.

DNA methods. E. coli cells were transformed by the method of Hanahan (1983). Plasmids were isolated from $E$. coli and $L$. lactis cells by the alkaline method (Maniatis et al., 1982) except that mutanolysin ( 5 to $50 \mathrm{U} \mathrm{ml}^{-1}$ ) was used with lysozyme at $37^{\circ} \mathrm{C}$ for $30 \mathrm{~min}$ to disrupt the cell wall of $L$. lactis. The chromosomal DNA of $L$. lactis and $B$. subtilis was isolated according to Marmur (1961). Restriction enzyme digestions, ligations, gel electrophoresis and Southern blotting were done as described by Maniatis et al. (1982). Hybridization conditions were similar to those described previously (Koivula et al., 1991 b). The same conditions were used for nick-translated probes and for terminally labelled oligonucleotide probes except that the hybridization was done at $T_{\mathrm{m}}-10^{\circ} \mathrm{C}\left(10^{\circ} \mathrm{C}\right.$ below the melting temperature of the probe) for $30 \mathrm{~min}$ and at $T_{\mathrm{m}}-20^{\circ} \mathrm{C}$ for $30 \mathrm{~min}$ when oligonucleotide probes were used. Polymerase chain reactions (PCRs) were done as recommended by the supplier of the AmpliTaq enzyme (Perkin-Elmer/Cetus).

DNA sequencing and sequence analysis. For DNA sequencing, the plasmids were denatured by alkali (Koivula et al., 1991b) and sequenced by the dideoxy chain termination method (Sanger et al., 1977) using $\left[\alpha^{-35}\right.$ S $]$ dATP deoxyadenosine $5^{\prime}-\alpha-\left[{ }^{35} S\right]$ thiotriphosphate [ $>1000 \mathrm{Ci} \mathrm{mmol}^{-1}$ (>37 $\mathrm{TBq} \mathrm{mmol}^{-1}$ ); Amersham] as the labelled nucleotide. The DNA polymerase used was Sequenase (USB) and the protocol recommended by the manufacturer was followed. Universal primers were used to sequence the inserts in pUC18 and pUC19 together with specific primers made on an Applied Biosystems DNA synthesizer model 381A. Both strands of the DNA were sequenced.

The sequence was analysed with the GCG package (Devereux et al., 1984) and the PCGENE set of programs (Intelligenetics). The protein sequence data banks were searched with the FASTA program (Pearson \& Lipman, 1988).

\section{Results and Discussion}

\section{Cloning of the ribosomal operon fragment}

We have previously isolated promoter fragments from $L$. lactis (Koivula et al., 1991 b). Plasmid pKTH1816 is one of the constructions that was obtained. It contains $2.8 \mathrm{~kb}$ of $L$. lactis chromosomal DNA in front of a promoterless chloramphenicol acetyltransferase gene (cat) in a promoter probe vector pKTH1750. The promoter $(\mathrm{P} 1)$ was first localized by sequencing. The promoter P1 was initially identified by sequencing. Its localization was supported by primer extension mapping of the 5 -end of the cat-specific transcript produced by the plasmid construct in L. lactis (Koivula et al., 1991 b). Downstream of the promoter, we found three ORFs, which were identified as initiation factor IF1 and ribosomal proteins $B$ and S13 (Table 1).

The entire chromosomal fragment was sequenced to determine the organization of this region in L. lactis in more detail. According to the sequence data, the insert of pKTH1816 was 2848 bp long. It was composed of three Sau3AI fragments (A, 1470 bp; B, 234 bp; C, 1144 bp; see Fig. 1a), which was unexpected since the chromosomal fragments originated from a complete Sau3AI digestion. The size of the insert was determined previously by restriction enzyme digestions using EcoRI, PvuII, BclI and PstI, but not Sau3AI, since a single Sau3AI fragment was expected.

Southern hybridization was used to analyse whether the three Sau3AI fragments were adjacent on the chromosome. L. lactis chromosomal DNA was digested with EcoRI, HindIII and Sau3AI, and with the enzyme combinations EcoRI-HindIII and HaeII-EcoRI. The digestions were hybridized with $\left[\gamma^{-32}\right.$ P]rATP-labelled oligonucleotides 466 (5'-TCTGTAGAATAATGCCC$\left.3^{\prime}\right)$ and 468 (5'-GTGATAAGTTGCTCCAC-3'), which were used for sequencing the fragments $A$ and $C$, respectively. The results indicated that the fragments $A$ and $\mathrm{C}$ were not colinear on the $L$. lactis chromosome (data not shown). There was no suitable probe for the small B-fragment, but the hybridization results with oligonucleotide 468 suggested that it is not colinear with the C-fragment.

The C-fragment (Fig. 1a), which was the Sau3AI fragment located closest to the cat reporter gene, contained the promoter $\mathrm{P} 1$ and the ORFs coding for IF1, $B$ and S13. Upstream from the promoter another ORF was identified, which coded for a carboxy-terminal fragment of a protein homologous to Adk. This ORF continued beyond the Sau3AI site between fragments B and $\mathrm{C}$. However, the B-fragment had no homology to Adk. This is a further indication that fragments B and C are not colinear on the L. lactis chromosome.

Because the entire $a d k$ gene was not in the C-fragment, we decided to clone an additional DNA fragment to complete the $a d k$ sequence. The cloned region of $L$. lactis had an organization similar to the $B$. subtilis spc- $\alpha$ region, except for the absence of the map gene between $a d k$ and inf $A$. In $B$. subtilis, the $\sec Y$ gene is localized immediately upstream of adk (Nakamura et al., 1990), and so we assumed that in $L$. lactis $\sec Y$ may also be located upstream from the $a d k$ gene. The sequences of the SecY proteins of both $E$. coli (Cerretti et al., 1983) and $B$. subtilis (Nakamura et al., 1990; Suh et al., 1990) are known and they contain several nearly identical amino acid stretches. This allowed us to design an oligonucleotide (465) to clone the missing 5'-region of $a d k$ and the 3 'region of $\sec Y$ by using the PCR. The oligonucleotide 465 was synthesized with an inosine (I), or a mixture of $A$ and $\mathrm{T}$, or $\mathrm{T}$ and $\mathrm{C}$, at the third nucleotide of most codons to allow binding irrespective of the identity of the third nucleotide in the codon; for serine a codon IIA/T was used (Fig. 1b).

First, Southern hybridization was done to confirm that oligonucleotide 465 binds efficiently to the chromosomal DNA of L. lactis. Oligonucleotide $\mathbf{4 6 5}$ was labelled with 
(a)

L. lactis chromosomal DNA
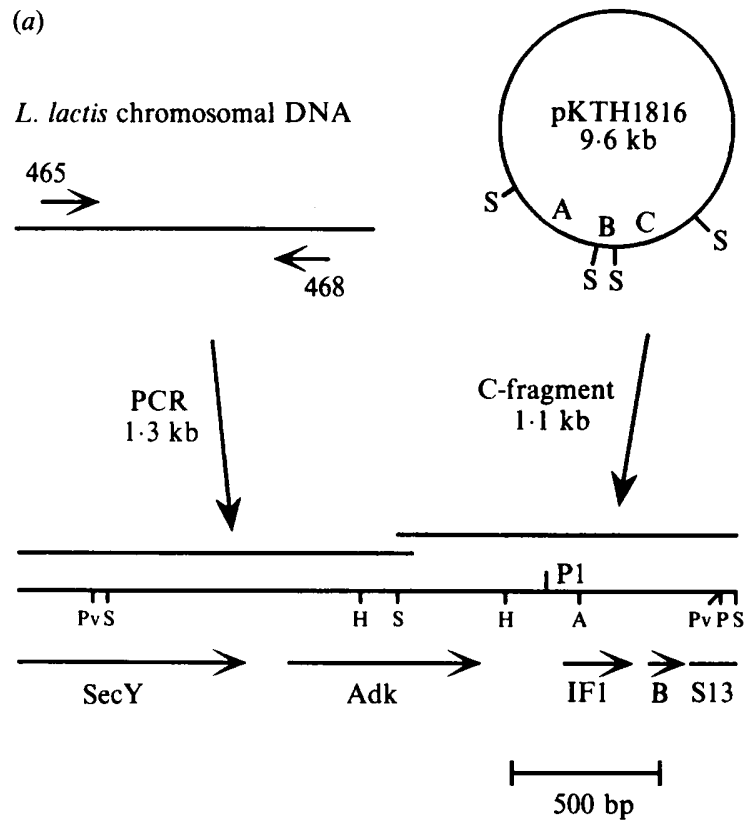

(b)
SecY, E. coli
184-GlyAsnglyI leSerI leI leI lePheAlaglyI leVal-196
SecY, B. subtilis
176-GlyAsnglyI leSer IleI lel lePheAlaglyl leVal-188
Oligonucleotide 465

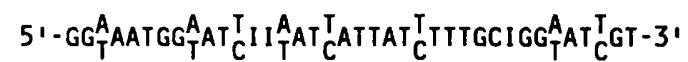

Fig. 1. (a) Plasmid pKTH1816 contains three Sau3AI (S) fragments - A, B, and C - in the insert. The C-fragment contains the 3'-end of the adk gene, the $5^{\prime}$-end of the $r p s M(\mathrm{~S} 13)$ gene and the inf $A$ and $r p m J(B)$ genes. The sequence of the C-fragment was extended in the $5^{\prime}-$ direction by cloning and sequencing a PCR fragment, which contained the $5^{\prime}$-region of $a d k$ and the $3^{\prime}$-region of $\sec Y$. The primers used in PCR are indicated as 465 and 468 . (b) Oligonucleotide 465 was based on an identical region between the SecY proteins from $E$. coli (Cerretti et al., 1983) and B. subtilis (Suh et al., 1990). The amino acid residues indicating the location of the fragments in the SecY proteins are indicated. Restriction enzyme abbreviations: A, AccI; H, HindIII; P, PstI; Pv, PvuII; S, Sau3AI.

Table 1. Comparison of $L$. lactis proteins to related proteins aa, amino acid.

\begin{tabular}{|c|c|c|c|}
\hline $\begin{array}{c}\text { L. lactis } \\
\text { protein (size) }\end{array}$ & $\begin{array}{c}\text { Identical } \\
\text { amino acids }\end{array}$ & Homologous protein & Reference \\
\hline Adk (215 aa) & $\begin{array}{l}60 \% \\
46 \% \\
42 \% \\
38 \% \\
30 \%\end{array}$ & $\begin{array}{l}\text { B. subtilis }(217 \text { aa) } \\
\text { E. coli }(214 \text { aa) } \\
\text { Paracoccus denitrificans }(217 \mathrm{aa})^{*} \\
\text { Saccharomyces cerevisiae }(222 \mathrm{aa}) \\
\text { Mycoplasma capricolum }(213 \mathrm{aa})\end{array}$ & $\begin{array}{l}\text { Nakamura et al. }(1990) \\
\text { Brune et al. }(1985) \\
\text { Spürgin et al. }(1989) \\
\text { Proba et al. }(1987) \\
\text { Ohkubo et al. }(1987)\end{array}$ \\
\hline IFI (72 aa) & $\begin{array}{l}81 \% \\
70 \% \\
70 \%\end{array}$ & $\begin{array}{l}\text { B. subtilis }(72 \text { aa }) \\
\text { E. coli }(71 \text { aa })^{*} \\
\text { Marchantia polymorpha }(78 \text { aa }) \dagger\end{array}$ & $\begin{array}{l}\text { Boylan et al. (1989) } \\
\text { Pon et al. (1979); Sands et al. (1987) } \\
\text { Ohyama et al. (1986) }\end{array}$ \\
\hline B (38 aa) & $\begin{array}{l}86 \% \\
87 \% \\
62 \%\end{array}$ & $\begin{array}{l}\text { B. subtilis }(37 \text { aa) } \\
\text { B. stearothermophilus }(37 \text { aa)* } \\
\text { E. coli }(38 \text { aa) }\end{array}$ & $\begin{array}{l}\text { Boylan et al. }(1989) \\
\text { Tanaka et al. }(1984) \\
\text { Cerretti et al. }(1983)\end{array}$ \\
\hline S13 (51 aa; N-terminus) & $\begin{array}{l}65 \% \\
58 \% \\
48 \%\end{array}$ & $\begin{array}{l}\text { E. coli }(121 \text { aa }) \\
\text { B. stearothermophilus }(119 \text { aa })^{*} \\
\text { E. coli }(118 \text { aa })\end{array}$ & $\begin{array}{l}\text { Boylan et al. (1989) } \\
\text { Brockmöller \& Kamp (1988) } \\
\text { Bedwell et al. (1985) }\end{array}$ \\
\hline
\end{tabular}

* Sequences determined by peptide sequencing; others were deduced from the nucleic acid sequence.

$\dagger$ Liverwort chloroplast protein. 
SecY

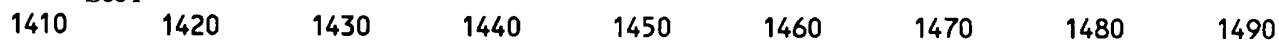

TATTTACTTAAACGTAAATATGCAGGATITATGGATAATCCACTTGAAACAAAATAAAATCTTGTCATTAGACAAGGTTTTCTTTATTT

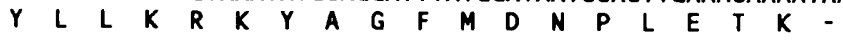

$\begin{array}{llllllll}1500 & 1510 & 1520 & 1530 & 1540 & 1550 & 1560 & 1570\end{array}$

ITCAGTAAAAATACGCTAAAATAGTGTAGGTAAAAGACAGTGTACATCTGCATTTTACTGACAGAGCTGTCAGTAATTTATAAAATCAAA Adk

$\begin{array}{lllllllll}1590 & 1600 & 1610 & 1620 & 1630 & 1640 & 1650 & 1660 & 1670\end{array}$ ATCAGGAGAAAACAAAATGAATTIATTAATCATGGGACTTCCAGGAGCTGGTAAAGGAACTCAAGCCGAATITATCGTTAAAAATTATGG $\begin{array}{llllllllllllllllllllllllllll}M & N & L & L & I & M & G & L & P & G & A & G & K & G & T & Q & A & E & F & I & V & K & N & Y & G\end{array}$

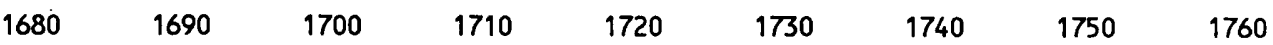

TGTAAACCATATITCAACAGGAGATATGTICCGTGCAGCGATGAAAAATGAAACAGAAATGGGTAAACTTGCTAAATCITTTATTGATAA

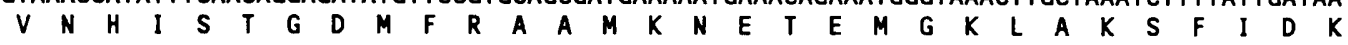

$\begin{array}{lllllllll}1770 & 1780 & 1790 & 1800 & 1810 & 1820 & 1830 & 1840 & 1850\end{array}$ AGGTGAACTCGITCCTGATGAAGTAACCAATGGTATTGTCAAAGAACGTTTAGCACAAGATGATATCAAAGCTTCAGGTTTCTTGCTTGA

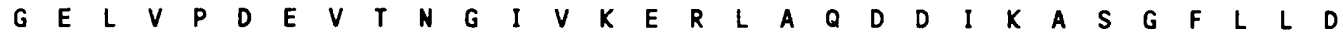

$\begin{array}{lllllllll}1860 & 1870 & 1880 & 1890 & 1900 & 1910 & 1920 & 1930 & 1940\end{array}$ TGGATACCCACGTACGATTGACCAAGCGCATGCTCTTGATACAATGCTTGAAGAACTTGGCATTAAACT TGATGCTGTTGTAAATATTGT

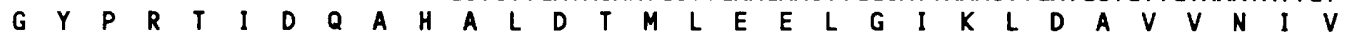

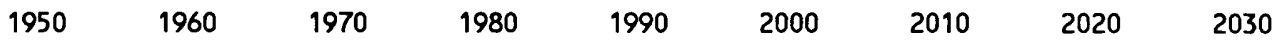
TGTTAATCCAAATATITTGGTTGATCGITTAAGTGGTCGTTACATCTGCCGTAATTGTGGAGCAACTTATCACAAAATITTCAACCCAAC

$\begin{array}{llllllllllllllllllllllllllllll} & N & P & N & I & L & V & D & R & L & S & G & R & Y & I & C & R & N & C & G & A & T & Y & H & K & I & F & N & P & T\end{array}$

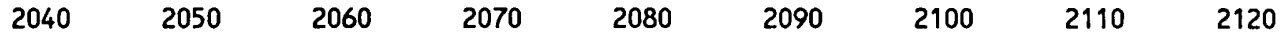
TAAAGTTGAAGGAACTTGTGACGITTGTGGTAGCCATGACCTTTACCAACGTGCTGATGATGTACCAGAAACAGTTAAAAACCGTTTAGA $\begin{array}{llllllllllllllllllllllllllllll}K & V & E & G & T & C & D & V & C & G & S & H & D & L & Y & Q & R & A & D & D & V & P & E & T & V & K & N & R & L & D\end{array}$

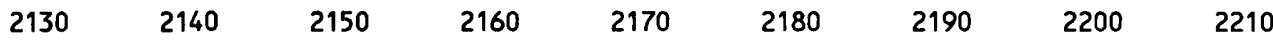
TGTCAACAT CAAAGAATCTGCGCCAAT TAT TGAACATTACACTGAACT TGGACTTGTTAAAAATATCGAAGGCGAACAAGAAATTAGTCA $\begin{array}{llllllllllllllllllllllllllllllll} & N & I & K & E & S & A & P & I & I & E & H & Y & T & E & L & G & L & V & K & N & I & E & G & E & Q & E & I & S & Q\end{array}$

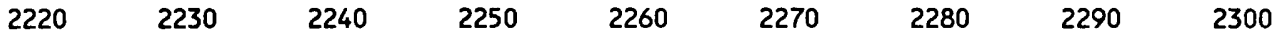
AGTGACAGATGATATTAAAAAAGTIITAGGCTAATAAATCATAAAACCTCTGTCAGAGGTITITTATITIAAATATGAAAAATGAAAGAT

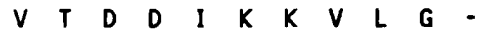

$\begin{array}{llllllll}2310 & 2320 & 2330 & 2340 & 2350 & 2360 & 2370 & 2380\end{array}$ AAAATTTACTGACAGAAAAGTCAACAAGCTTAAAAATAAAAAGAAACACCCGAAAGCATTGCCATAGGTACICTTATCAGATAATCTGAA

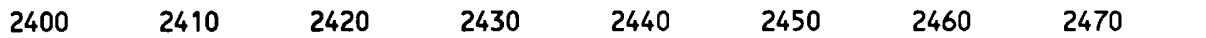
AATAAAAATGGACTCAGGCTAGAAAAATAAAGGCTITTATGAAAGAAAGACITGCATTTGTTGTTGAAAAAIGCIAAAATACATAAGTCC $2490 \quad 2500 \quad 2510 \quad 2520 \quad 2530 \quad 2540 \quad 2550 \quad 2560 \quad 2570$ GACTITITAGATATATITAAATTTGTATITATATCTITCGgGAAATITITAAGGAGGTACTITTGCITGGCAAAAGATGATGTAATTGAA $M$ A K D D $D$ V I E

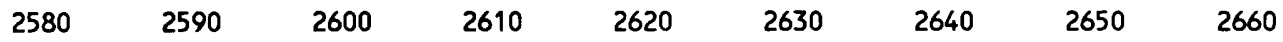
GTAGACGGCAAAGTCGTTGACACCATGCCGAATGCGATGTTCACTGTTGAACTCGAAAATGGTCACCAAGTCTTGGCGACGATTTCAGGA $V$ D G K V V D T M P N A M F T V E L E N G H Q V L A T I S G $\begin{array}{lllllllll}2670 & 2680 & 2690 & 2700 & 2710 & 2720 & 2730 & 2740 & 2750\end{array}$ AAAATTCGTAAGAATTATATCCGTATCTTGCCTGGAGACAAGGTTCAAGTTGAACTCTCACCATACGATTTGACACGCGGACGAATTACT $\begin{array}{llllllllllllllllllllllllllllll}K & I & R & K & N & Y & I & R & I & L & P & G & D & K & V & Q & V & E & L & S & P & Y & D & L & T & R & G & R & I & T\end{array}$

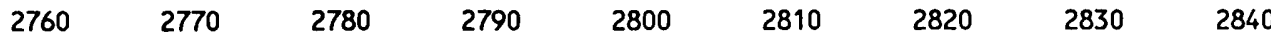
TACCGATTTAAGTAATCCGGACATTCATTGAGTGCATGATGCACAGTAACCATAGAAAGGAGACACAATGAAAGTAAGACCATCAGTTA $Y R F K$ - $M K V R F$

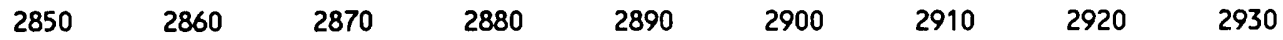
AACCAATCTGCGAATACTGTAAAGTTATTCGTCGTAACGGTCGTGTAATGGTAATTTGCCCTGCCAATCCAAACACAAACAACGTCAGG

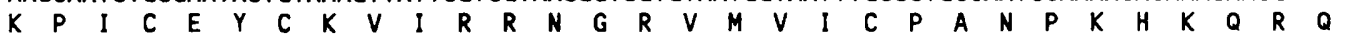
S13

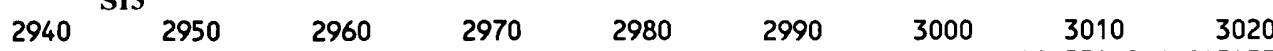
GATAGAAAGGAAATAGAAAAATATGGCTCGTTTTGCTGGAGTTGATAT TCCAAACGAAAAACGCATTGTTATITCATTAACATACGTATT

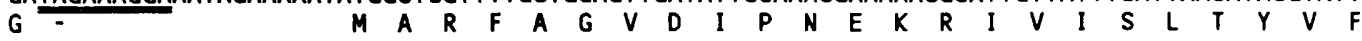

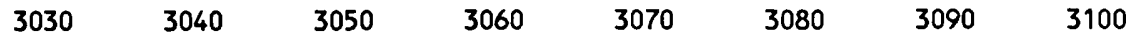
CGGTGTTGGACTICAAACATCTAAGAAAGTACTTGCAGCTGCAGGTGTTICAGAAGATATCCGTACTAAAGATITGACATCAGATC

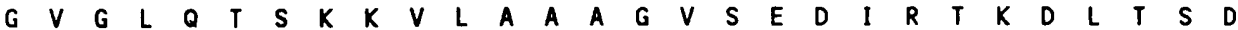


$\left[\gamma^{-32} \mathrm{P}\right] \mathrm{AATP}$ and used as a hybridization probe. This probe identified a $1.7 \mathrm{~kb}$ HindIII and a $1.6 \mathrm{~kb}$ HindIII$E c o$ RI fragment from the chromosomal DNA of $L$. lactis (data not shown). The probe also hybridized to a $6 \mathrm{~kb}$ EcoRI fragment of chromosomal DNA of $B$. subtilis IH6064, which was used as a control.

Oligonucleotides 465 and 468 were used in the PCR to clone the 5'-end of the adk gene from the chromosomal DNA of L. lactis (Fig. 1a). PCR yielded a $1.3 \mathrm{~kb}$ fragment which was cloned into the SmaI site of pUC19 and sequenced. Since the AmpliTaq polymerase used in the PCR makes errors during DNA synthesis, the PCR fragment was sequenced from three independent clones. In case of mismatches the nucleotide that was the same in two out of three clones was chosen. The sequence of the fragment was $1347 \mathrm{bp}$ long, and contained the 3'region of $\sec Y$ and the $5^{\prime}$-region of $a d k$ which overlapped with the 3 '-region of the C-fragment (Fig. 1). There were 10 differences between the three clones: six of these were $T \rightarrow C$ changes but there were also two $A \rightarrow G$, one $A \rightarrow C$ and one $T \rightarrow G$ change.

\section{Organization of the ribosomal operon fragment}

The nucleotide sequence of the region including the $a d k$, inf $A, r p m J(\mathrm{~B})$ and $r p s M(\mathrm{~S} 13)\left(5^{\prime}\right.$-region) genes is shown in Fig. 2. The sequences for the $3^{\prime}$-end region of $r p l O$ (L15) and sec $Y$ have already been published (Koivula $e t$ al. 1991a). The genes begin with the initiation codon ATG except for inf A, which begins with TTG. In front of the putative initiation codon of each gene there is a nucleotide sequence which shows a close complementarity to the 3 '-end of the $16 \mathrm{~S}$ rRNA of $L$. lactis DSM20250 (Ludwig et al., 1985) and which resembles ribosomalbinding sites (RBSs) previously isolated from lactococci (de Vos, 1987). The calculated free energies $(\Delta G)$ (Tinoco et al., 1973) for the binding of the putative RBSs were $-11.6 \mathrm{kcal}(-48 \mathrm{~kJ})$ for $a d k,-18.1 \mathrm{kcal}(-76 \mathrm{~kJ})$ for inf $A,-18.0 \mathrm{kcal}(-75 \mathrm{~kJ})$ for rpmJ and $-18.0 \mathrm{kcal}$ $(-75 \mathrm{~kJ})$ for $r p s M$. The difference between the $\Delta G$ values of $a d k$ and the genes involved in protein synthesis may indicate a more efficient translation of the latter genes in accordance with studies in $B$. subtilis (Sharp et al., 1990).

The previously isolated promoter P1 is located in the region between $a d k$ and inf $A$. The promoter was isolated with a cat-based promoter probe plasmid by chloramphenicol selection in L. lactis (Koivula et al., $1991 \mathrm{~b}$ ), and the $5^{\prime}$-end of the transcript was determined from a plasmid construction. It is not known how this promoter functions when located in the chromosome, but it is notable that promoter P1 was found in a search for strong chromosomal promoters. In $E$. coli there is a promoter $(\mathrm{P} \alpha)$ located between the B and $\mathrm{S} 13$ genes (Post et al., 1980), but the majority of the transcripts for the $\alpha$ region originate upstream from the $s p c$ operon (Cerretti et al., 1983). In B. subtilis, there is a weak promoter activity in the region containing IF1, B and S13, but the major promoter encoding the $\alpha$-region lies well upstream from this area (Boylan et al., 1989).

The initiation factor IF 1 and the ribosomal proteins B and $\mathrm{S} 13$ of $L$. lactis show a high degree of similarity to their counterparts in E. coli and B. subtilis (Table 1). This may reflect the functional roles of these proteins in ribosomes. Ribosomal subunits interact closely with each other which reduces the acceptable mutations in the proteins. In contrast, $L$. lactis adenylate kinase has a significantly lower degree of similarity to the same enzyme of other species, as is typical for globular enzymes. Only the catalytic residues and the inner core domain are highly conserved while the residues facing outside may change quite freely, allowing much divergence between different species (Chothia \& Lesk, 1987).

\section{Conclusions}

The organization of the lactococcal genes in the chromosomal DNA fragment sequenced during this work is quite similar to the gene order in the corresponding region in $B$. subtilis. The major difference is the absence of the map gene from Lactococcus. The organization of the $s p c$ and $\alpha$ operons in the Gram-negative $E$. coli is essentially similar to that in $B$. subtilis except for the absence of adk, map and inf A in E. coli. Another Gramnegative bacterium, Mycoplasma capricolum, contains the $a d k$ gene downstream from the sec $Y$ gene, but there is no sequence further downstream (Ohkubo et al., 1987). Thus, there appears to be species-specific differences even though the organization is quite similar in the regions that have been determined.

The authors are grateful to Dr L. Paulin for the synthesis of oligonucleotides, and to Drs M. Sibakov and M. Simonen for critical reading of the manuscript. This work was supported by grants from the Foundation for Biotechnical and Industrial Fermentation Research.

Fig. 2. Nucleotide sequence for the $L$. lactis gene cluster encoding Adk, IF 1 and ribosomal proteins. Promoter P1 is underlined and the $5^{\prime}$-end of the transcript, as determined by S1 mapping (Koivula et al., 1991b), is marked by an asterisk at 2477 bp. The RBSs are, underlined twice. The deduced amino acid sequences are given below the nucleotide sequence. An inverted repeat structure is indicated by arrows. The genes are identified by the name of the protein close to the RBS. The C-fragment starts at 1963 bp and the PCR fragment ends at $2013 \mathrm{bp}$. The numbering is consistent with the upstream region containing the 3'-end of $r p I O$ (L15) and $\sec Y$, which has been published previously (Koivula et al. 1991a). The nucleotide sequence has been submitted to EMBL and given the accession number X59250. 


\section{References}

BaChMaNN, B. J. (1990). Linkage map of Escherichia coli K-12, edition 8. Microbiological Reviews 54, 130-197.

Bedwell, D., Davis, G., Gosink, M., Post, L., Nomura, M., Kestler, H., Zengel, J. M. \& Lindahl, L. (1985). Nucleotide sequence of the alpha ribosomal protein operon of Escherichia coli. Nucleic Acids Research 13, 3891-3903.

Ben-Bassat, A., Bauer, K., Chang, S.-Y., Myambo, K., Boosman, A. $\&$ Chang, S. (1987). Processing of the initiation methionine from proteins: properties of the Escherichia coli methionine aminopeptidase and its gene structure. Journal of Bacteriology 169, 751-757.

Boylan, S. A., SuH, J.-W., Thomas, S. M. \& Price, C. W. (1989). Gene encoding the alpha core subunit of Bacillus subtilis RNA polymerase is cotranscribed with the genes for initiation factor 1 and ribosomal proteins B, S13, S11, and L17. Journal of Bacteriology 171, 25532562.

BROCKMÖLleR, J. \& KAMP, R. M. (1988). Cross-linked amino acids in the protein pair S13-S19 and sequence analysis of protein S13 of Bacillus stearothermophilus ribosomes. Biochemistry 27, 3372-3381.

Brune, M., SchumanN, R. \& Wirtinghofer, F. (1985). Cloning and sequencing of the adenylate kinase gene ( $a d k$ ) of Escherichia coli. Nucleic Acids Research 13, 7139-7151.

Cerretti, D. P., Dean, D., Davis, G. R., Bedwell, D. M. \& Nomura, M. (1983). The spc ribosomal protein operon of Escherichia coli: sequence and cotranscription of the ribosomal protein genes and a protein export gene. Nucleic Acids Research 11, 2599-2616.

CHOTHIA, C. \& LESK, A. M. (1987). The evolution of protein structures. Cold Spring Harbor Symposia on Quantitative Biology 52, 399-405.

DevereuX, J., Haeberli, P. \& Smithies, O. (1984). A comprehensive set of sequence analysis programs for the VAX. Nucleic Acids Research 12, 387-395.

Gasson, M. J. (1983). Plasmid complements of Streptococcus lactis NCDO 712 and other lactic Streptococci after protoplast-induced curing. Journal of Bacteriology 154, 1-9.

HANAHAN, D. (1983). Studies on transformation of Escherichia coli with plasmids. Journal of Molecular Biology 166, 557-580.

Henkin, T. M., Moon, S. H., Mattheakis, L. C. \& Nomura, M. (1989). Cloning and analysis of the $s p c$ ribosomal protein operon of Bacillus subtilis: comparison with the spc operon of Escherichia coli. Nucleic Acids Research 17, 7469-7486.

Koivula, T., Palva, I. \& Hemilä, H. (1991 a). Nucleotide sequence of the $\sec Y$ gene from Lactococcus lactis and identification of conserved regions by comparison of four SecY proteins. FEBS Letters 288, 114-118.

Koivula, T., Sibakov, M. \& Palva, I. (1991b). Isolation and characterization of Lactococcus lactis subsp. lactis promoters. Applied and Environmental Microbiology 57, 333-340.

LINDAHL, L. \& ZENGEL, J. M. (1986). Ribosomal genes in Escherichia coli. Annual Review of Genetics 20, 297-326.

LudWiG, W., SeEWAldT, E., KilpPer-Bälz, R., Schleifer, K. H., Magrum, L., Woese, C. R., Fox, G. E. \& Stackebrand, E. (1985). The phylogenetic postion of Streptococcus and Enterococcus. Journal of General Microbiology 131, 543-551.

Maniatis, T., Fritsch, E. F. \& SAmbrook, J. (1982). Molecular Cloning: a Laboratory Manual. Cold Spring Harbor, NY: Cold Spring Harbor Laboratory.

MARmuR, J. (1961). A Procedure for the isolation of deoxyribonucleic acid from microorganisms. Journal of Molecular Biology 3, 208-218.

Nakamura, K., Nakamura, A., Takamatsu, H., Yoshikawa, H. \& YAMANE, K. (1990). Cloning and characterization of a Bacillus subtilis gene homologous to $E$. coli secY. Journal of Biochemistry 107 , 603-607.

OHKubo, S., Muto, A., Kawauch, Y., Yamao, F. \& Osawa, S. (1987). The ribosomal protein gene cluster of Mycoplasma capricolum. Molecular and General Genetics 210, 314-322.
Ohyama, K., Fukuzawa, H., Kohchi, T., Shirai, H., Sano, T., Sano, S., Umesono, K., Shiki, Y., Takeuchi, M., Chang, Z., Aota, S.-I., INOKUCHI, H. \& OZEKI, H. (1986). Chloroplast gene organization deduced from complete sequence of liverwort Marchantia polymorpha chloroplast DNA. Nature, London 322, 572-574.

Palva, I. (1982). Molecular cloning of $\alpha$-amylase gene from Bacillus amyloliquefaciens and its expression in B. subtilis. Gene 19, 81-87.

Pearson, W. R. \& LipMan, D. J. (1988). Improved tools for biological sequence comparison. Proceedings of the National Academy of Sciences of the United States of America 85, 2444-2448.

Piggot, P. J., Amjad, M., Wu, J. J., Sandoval, H. \& Castro, J. (1990). Genetic and physical maps of Bacillus subtilis 168 . In Molecular Biological Methods for Bacillus, pp. 493-540. Edited by C. R. Harwood \& S. M. Cutting, New York: John Wiley.

Pon, C. L., Wittmann-Liebold, B. \& Gualerzi, C. (1979). Structurefunction relationships in Escherichia coli initiation factors. II. Elucidation of the primary structure of initiation factor IF-1. FEBS Letters 101, 157-160.

Post, L. E., ARfSTEN, A. E., DAvis, G. R. \& Nomura, M. (1980). DNA sequence of the promoter region for the $\alpha$ ribosomal protein operon in Escherichia coli. Journal of Biological Chemistry 255, 4653-4659.

Proba, K., Tomasselli, A. G., Nielsen, P. \& Schulz, G. E. (1987). The cDNA sequence encoding cytosolic adenylate kinase from baker's yeast (Saccharomyces cerevisiae). Nucleic Acids Research 15, 7187.

Sands, J. F., Cummings, H. S., Sacerdot, C., Dondon, L., Grunberg-Manago, M. \& Hershey, J. W. B. (1987). Cloning and mapping of inf $A$, the gene for protein synthesis initiation factor IF1. Nucleic Acids Research 15, 5157-5168.

SANGer, F., Nicklen, S. \& Coulson, A. R. (1977). DNA sequencing with chain-terminating inhibitors. Proceedings of the National Academy of Sciences of the United States of America 74, 5463-5467.

Schulz, G. E., Schlitz, E., Tomasselli, A. G., Frank, R., Brune, M., Wittinghofer, A. \& SChirmer, R. H. (1986). Structural relationships in the adenylate kinase family. European Journal of Biochemistry 161, 127-132.

Sharp, P. M., Higgins, D. G., Shields, D. C., Devine, K. M. \& Hoch, J. A. (1990). Bacillus subtilis gene sequences. In Genetics and Biotechnology of Bacilli, vol. 3, pp. 89-98. Edited by M. M. Zukowski, A. T. Ganesan \& J. A. Hoch. New York: Academic Press.

Suh, J.-W., Boylan, S. A., Thomas, S. M., Dolan , K. M., Oliver, D. B. \& PRICE, C. W. (1990). Isolation of a sec $Y$ homologue from Bacillus subtilis: evidence for a common protein export pathway in eubacteria. Molecular Microbiology 4, 305-314.

Spürgin, P., Tomasselli, A. G. \& Schiltz, E. (1989). The amino acid sequence of adenylate kinase from Paracoccus denitrificans ands its relationship to mitochondrial and microbial adenylate kinases. European Journal of Biochemistry 179, 621-628.

TANAKA, I., Kimura, M., Kimura, J. \& DiJK, J. (1984). The amino acid sequence of two small ribosomal proteins from Bacillus stearothermophilus. FEBS Letters 166, 343-346.

TERZAGHI, P. E. \& SANDINE, W. E. (1975). Improved medium for lactic streptococci and their bacteriophages. Applied and Environmental Microbiology 29, 807-813.

Tinoco, I., Borer, P. N., Dengler, B., Levine, M. D., Uhlenbeck, O. C., Crothers, D. M. \& Gralla, J. (1973). Improved estimation of secondary structure in ribonucleic acids. Nature, London 246, 4041.

DE Vos, W. M. (1987). Gene cloning and expression in lactic streptococci. FEMS Microbiological Reviews 46, 281-295.

YaNISCh-PerRon, C., VieIRA, J. \& MEssing, J. (1985). Improved M13 phage cloning vectors and host strains: nucleotide sequence of the M13mp18 and pUC19 vectors. Gene 33, 103-119. 